\title{
Casticin inhibits the activity of transcription factor Sp1 and the methylation of RECK in MGC803 gastric cancer cells
}

\author{
FAN YANG ${ }^{1,2}$, KEFEI HE ${ }^{1}$, LI HUANG $^{3}$, LINGYAN ZHANG ${ }^{4}$, AIXUE LIU ${ }^{5}$ and JIREN ZHANG ${ }^{1}$ \\ ${ }^{1}$ Department of Oncology, Zhujiang Hospital, Southern Medical University, Guangzhou, Guangdong 510280; \\ ${ }^{2}$ Department of Basic Medicine, Xiangnan University, Chenzhou, Hunan 423000; ${ }^{3}$ Department of Oncology, \\ The First Affiliated Hospital of Gannan Medical University, Ganzhou, Jiangxi 341000; ${ }^{4}$ Medical Department \\ of Chongqing Bishan People's Hospital, Chongqing 402760; ${ }^{5}$ Department of Oncology, \\ The Second People's Hospital of Shenzhen, Shenzhen, Guangdong 518000, P.R. China
}

Received July 17, 2015; Accepted September 27, 2016

DOI: $10.3892 /$ etm.2016.4003

\begin{abstract}
The present study investigated the effect of casticin on reversion-inducing-cysteine-rich protein with kazal motifs $(R E C K)$ gene expression and intracellular methylation levels in MGC803 gastric cancer cells. Cells were treated with 1, 10 and $30 \mu \mathrm{mol} / \mathrm{l}$ casticin. Western blotting and reverse transcription-quantitative polymerase chain reaction assays were performed to determine the protein expression and mRNA levels of RECK and DNA methyltransferase 1 (DNMT1), respectively. High-performance liquid chromatography coupled to electrospray ionization tandem mass spectrometry was used to detect RECK methylation. In addition, MGC803 cell proliferation was measured by an MTT assay and the DNA-binding activity of transcription factor Sp1 was determined using an enzyme-linked immunosorbent assay. The results demonstrated that treatment with 1,10 and $30 \mu \mathrm{mol} / 1$ casticin significantly increased RECK protein expression and mRNA levels. In addition, casticin $(30 \mu \mathrm{mol} / \mathrm{l})$ decreased RECK promoter methylation levels by $31 \%$, global DNA methylation levels by $39 \%$ and nuclear methylation activity by $71.6 \%$. Furthermore, casticin downregulated the mRNA levels and protein expression of DNMT1. The MTT assay demonstrated that MGC803 cell proliferation was inhibited by casticin treatment and DNA binding assays indicated that casticin reduced the DNA-binding activity of Sp1. The present study therefore indicated that casticin inhibits the proliferation of gastric cancer MGC 803 cells by upregulating RECK gene expression and reducing intracellular methylation levels.
\end{abstract}

Correspondence to: Professor Jiren Zhang, Department of Oncology, Zhujiang Hospital, Southern Medical University, 253 Industrial Road, Guangzhou, Guangdong 510280, P.R. China E-mail: zhangjiren2015@163.com

Key words: gastric cancer, methylation, casticin, reversion-inducing-cysteine-rich protein with kazal motifs, transcription factor $\mathrm{Sp} 1$

\section{Introduction}

Gastric cancer is the most common tumor of the human digestive system and has relatively high morbidity and mortality rates compared with other types of digestive system cancer (1). Patients with gastric cancer usually exhibit ambiguous symptoms, high degrees of malignancy and early distal metastasis (2). Similar to other malignant tumors, gastric cancer develops by a complex process involving multiple steps and factors, including genetic and phenotypic changes in cells (3).

Epigenetic changes, such as DNA methylation, have attracted increasing attention in the study of tumor occurrence (4). Under normal conditions, DNA methylation is a basic physiological process in biological organisms, which transforms cytosine into 5'-methylcytosine using DNA methyltransferases (DNMTs). Therefore, DNA methylation serves an important role in maintaining chromatin structures, DNA conformation, DNA stability and DNA-protein interactions (5). However, abnormal methylation of DNA in certain pathological conditions may deactivate tumor suppressor genes and activate oncogenes $(6,7)$. The deactivation of tumor suppressor genes, including $R E C K$ and $\mathrm{Ras}$ association domain family 1 isoform A (RASSF1A), is closely associated with the occurrence of gastric cancer (8-10). The RECK gene, first identified by Takahashi et al (11) is located on chromosome 9 and encodes a membrane-anchoring protein that inhibits matrix metalloproteinases (MMPs). MMPs can degrade basal lamina and extracellular matrix, facilitating the metastasis of tumor cells to connective tissues and the vascular wall (3).

It has been demonstrated that the RECK gene is expressed in the majority of normal tissues and cell lines, but is either not expressed or expressed at very low levels in tissues or cell lines from tumors including gastric cancer (12). In tissues from pancreatic, colon and breast cancer, levels of RECK gene expression are lower than those in adjacent healthy tissue (13). In addition, patients with increased $R E C K$ gene expression exhibit lower tumor invasion and higher survival rates than those with lower $R E C K$ gene expression (14). In tumor tissue with low $R E C K$ gene expression, the promoter region usually exhibits abnormal methylation $(15,16)$. It is widely accepted that the existence of oncogenes is necessary for the occurrence 
of cancer, however the deactivation of tumor-suppressor genes may be more common and important than the activation of oncogenes (17). Therefore, the RECK gene may suppress the expression of multiple MMPs at post-transcriptional levels and hence inhibit tumor invasion and metastasis.

Casticin is a type of polymethoxylated flavone containing C-3, C-6, C-7 and C-4' methoxy and C-3' and C-5 hydroxy substituents. It has been identified that the $\mathrm{C}-3$ and $\mathrm{C}-4$ ' methoxy and C-3' and C-5 hydroxy functional groups provide the strong anti-proliferative activity of this flavonoid (18). Casticin exhibits weaker cytotoxicity but greater selectivity than taxol, (the $\mathrm{IC}_{50}$ of taxol for tumor cells is at the nmol/l level, while the $\mathrm{IC}_{50}$ of casticin is at the $\mu \mathrm{mol} / \mathrm{l}$ level) (19). Although casticin has little or no effect on the apoptosis of normal cells and tissues, it is reported to have an inhibitory effect on the proliferation of malignant tumors (20-23). However, it is currently unclear whether casticin affects methylation of the RECK gene in gastric cancer cells. The current study aimed to investigate the effect of casticin on the methylation and expression of the RECK gene in MGC803 gastric cancer cells.

\section{Materials and methods}

Cells and cell culture. Human MGC803 gastric cancer cells (American Type Culture Collection, Manassas, VA, USA) were cultured using 6 -well plates $\left(10^{4}\right.$ per well) in RPMI-1640 medium supplemented with $10 \%$ fetal bovine serum (FBS; both Thermo Fisher Scientific, Inc., Waltham, MA, USA), $100 \mu \mathrm{g} / \mathrm{ml}$ penicillin and $100 \mu \mathrm{g} / \mathrm{ml}$ streptomycin (Sigma-Aldrich; Merck Millipore, Darmstadt, Germany) at $37^{\circ} \mathrm{C}$ in $5 \% \mathrm{CO}_{2}$ for $24 \mathrm{~h}$. For stimulation experiments, MGC803 cells were seeded in serum-free medium in 6 -well plates $\left(1 \times 10^{5} /\right.$ well) and cultured overnight. Cells were stimulated with 1,10 and $30 \mu \mathrm{mol} / 1$ casticin (Sigma-Aldrich; Merck Millipore) for indicative time intervals. Equal volumes of DMSO (Sigma-Aldrich; Merck Millipore) were used as the controls.

Reverse transcription-quantitative polymerase chain reaction $(R T-q P C R)$. Following treatment, total RNA was extracted from the cells and purified using TRIzol ${ }^{\circledR}$ reagent (Invitrogen; Thermo Fisher Scientific, Inc.) following the manufacturer's protocol. RNA was reversely transcribed into cDNA by a RevertAid First Strand cDNA Synthesis kit (Thermo Fisher Scientific, Inc.). A total of $2 \mu \mathrm{g}$ RNA was subject to RT-qPCR using SuperReal PreMix kit (Tiangen Biotech, Co., Ltd., Beijing, China). The primers used were as follows: $R E C K$, forward, 5'-ATCATTCCCGTCGATCACTATC-3' and reverse, 5'-ATA TGTCCAGAGCAAGTGCAAG-3'; DNA methyltransferase 1 (DNMT1) forward, 5'-AACCTTCACCTAGCCCCAG-3' and reverse, 5'-CTCATCCGATTTGGCTCTTCA-3'; $\beta$-actin forward, 5'-CATCCTGCGTCTGGACCTGG-3' and reverse, 5'-TAATGTCACGCACGATTTCC-3'. PCR amplification was performed on an ABI Prism ${ }^{\circledR} 7700$ (Applied Biosystems; Thermo Fisher Scientific, Inc.) as follows: $5 \mathrm{~min}$ at $95^{\circ} \mathrm{C}$; 40 cycles of $30 \mathrm{sec}$ at $95^{\circ} \mathrm{C}, 30 \mathrm{sec}$ at $60^{\circ} \mathrm{C}$ and $1 \mathrm{~min}$ at $72^{\circ} \mathrm{C}$. The $2^{-\Delta \Delta \mathrm{Ct}}$ method (24) was used to calculate the relative levels of target mRNAs and $\beta$-actin was used as a reference gene.

Western blotting. Following treatment, cells were centrifuged at $1,000 \times g$ and $4^{\circ} \mathrm{C}$ (Centrifuge 5418R; Eppendorf, Hamburg,
Germany) for $5 \mathrm{~min}$ and supernatants were subsequently discarded. Following two washes with ice-cold phosphate-buffered saline, cells were re-suspended using $200 \mu \mathrm{l}$ cell lysis buffer (P0013; Beyotime Institute of Biotechnology, Shanghai, China) for lysis on ice for $40 \mathrm{~min}$. Following centrifugation at $1,000 \times \mathrm{g}$ and $4^{\circ} \mathrm{C}$ for $15 \mathrm{~min}$, supernatants were collected. Protein samples were mixed with $2 \mathrm{X}$ sodium dodecyl sulfate (SDS) loading buffer and boiled for $5 \mathrm{~min}$ to induce denaturation. A total of $80 \mu \mathrm{g}$ protein was resolved using $12 \%$ SDS-polyacrylamide gel electrophoresis and electrotransferred to nitrocellulose membranes (Sigma-Aldrich; Merck Millipore) under $30 \mathrm{~V}$ at $4^{\circ} \mathrm{C}$. Following blocking at $4^{\circ} \mathrm{C}$ and washing with Tris-buffered saline with Tween-20 (TBST) for $30 \mathrm{~min}$, the membranes were incubated with polyclonal rabbit anti-human RECK (1:400; sc-28918) or DNMT1 antibodies $(1: 400$; sc-20701) or rabbit anti- $\beta$-actin antibodies $(1: 1,000$; sc-7210; all Santa Cruz Biotechnology, Inc., Dallas, TX, USA) at $4^{\circ} \mathrm{C}$ for $8 \mathrm{~h}$. After washing with TBST for $30 \mathrm{~min}$, the membrane was incubated with horseradish peroxidase (HRP)-labeled goat anti-rabbit immunoglobulin G antibody (1:5,000; sc-2054; Santa Cruz Biotechnology, Inc.) for $4 \mathrm{~h}$ at room temperature. After washing with TBST for $30 \mathrm{~min}$, bands were visualized by enhanced chemiluminescence (sc-2048; Santa Cruz Biotechnology, Inc.). The level of target protein expression in each sample was determined by normalizing protein band intensity to $\beta$-actin band intensity using Image J analysis software (version 1.46; National Institutes of Health, Bethesda, MD, USA). Tests were performed in triplicate.

Methylation activity determination. Following treatment with casticin, MGC803 cells $\left(1 \times 10^{7}\right)$ underwent genomic DNA extraction and purification using the DNeasy Blood \& Tissue kit (Qiagen $\mathrm{GmbH}$, Hilden, Germany). A total of $200 \mathrm{ng}$ genomic DNA was denatured at $100^{\circ} \mathrm{C}$ for $3 \mathrm{~min}$ and placed on ice for cooling. Afterwards, 1/10 (volume ratio) ammonium acetate $(0.1 \mathrm{~mol} / \mathrm{l}, \mathrm{pH} 5.3)$ and 2 units nuclease $\mathrm{P} 1$ were added. After $2 \mathrm{~h}$ incubation at $45^{\circ} \mathrm{C}, 1 / 10$ (volume ratio) $\mathrm{NH}_{4} \mathrm{HCO}_{3}(1 \mathrm{~mol} / \mathrm{l}$ ) and 0.002 units venom phosphodiesterase I were added prior to incubation at $37^{\circ} \mathrm{C}$ for $1 \mathrm{~h}$. Subsequently, 0.5 units alkaline phosphatase were added, followed by further incubation at $37^{\circ} \mathrm{C}$ for $1 \mathrm{~h}$. An EpiQuik DNMT Activity/Inhibition Assay Ultra Kit (EpiGentek, Farmingdale, NY, USA) was used to determine the methylation activity of nucleoprotein in MGC803 cells, following the manufacturer's protocol. For high-performance liquid chromatography coupled to electrospray ionization tandem mass spectrometry (HPLC-ESI-MS/MS) analysis of a 10- $\mu$ l sample, an Agilent 1100 series HPLC system was used (Agilent Technologies, Inc., Santa Clara, CA, USA). The Atlantis ${ }^{\mathrm{TM}} \mathrm{dC}_{18}$ column (inner diameter, $2.1 \mathrm{~mm}$; length, $150 \mathrm{~mm}$; particle size, $3 \mu \mathrm{m}$ ) was purchased from Waters Corporation (Milford, MA, USA) and the mobile phase was $0.1 \%$ formic acid-methanol with a flow rate of $0.2 \mathrm{ml} / \mathrm{min}$. The mode of electrospray ionization was positive ions, with the following conditions: Scanning range, 100-2,000 m/z; ion source temperature, $450^{\circ} \mathrm{C}$; electrospray voltage, $415 \mathrm{kV}$; cluster breaking voltage, $55 \mathrm{~V}$; entrance voltage, $6 \mathrm{~V}$; collision energy, $13 \mathrm{~V}$; air curtain pressure, $138 \mathrm{kPa}$; gas 1 pressure, $221 \mathrm{kPa}$; gas 2 pressure, $379 \mathrm{kPa}$; collision gas pressure, $41 \mathrm{kPa}(25)$. Analyst Software version 1.3.1 (AB SCIEX, Framingham, MA, USA) was used for data analysis. 
Table I. Effects of casticin on promoter methylation level, global DNA methylation level and methylation activity in nuclear extracts.

\begin{tabular}{lccc}
\hline Group & $\begin{array}{c}\text { Promoter methylation } \\
(\% \text { of control) }\end{array}$ & $\begin{array}{c}\text { Global DNA methylation } \\
(\% \text { of control })\end{array}$ & $\begin{array}{c}\text { Methylation activity in nuclear } \\
\text { extracts (activity unit) }\end{array}$ \\
\hline Control & 100 & 100 & $8.46 \pm 1.08$ \\
CAS $(1 \mu \mathrm{mol} / 1)$ & $87.14 \pm 6.31^{\mathrm{a}}$ & $86.81 \pm 10.41^{\mathrm{a}}$ & $6.06 \pm 1.36^{\mathrm{a}}$ \\
CAS $(10 \mu \mathrm{mol} / 1)$ & $77.56 \pm 5.47^{\mathrm{a}}$ & $71.38 \pm 4.22^{\mathrm{a}}$ & $3.2 \pm 1.24^{\mathrm{b}}$ \\
CAS $(30 \mu \mathrm{mol} / \mathrm{l})$ & $69.04 \pm 10.62^{\mathrm{b}}$ & $61.13 \pm 7.08^{\mathrm{b}}$ & $2.8 \pm 1.32^{\mathrm{b}}$ \\
\hline
\end{tabular}

${ }^{\mathrm{a}} \mathrm{P}<0.05 ;{ }^{\text {b }}<0.01$ vs. control. CAS, casticin.

MTT assay. MGC803 cells (100 $\mu \mathrm{l})$ were seeded onto 96-well plates $\left(\sim 3 \times 10^{3}\right.$ cells per well) containing $100 \mu$ RPMI-1640 medium supplemented with $5 \%$ fetal bovine serum (both Thermo Fisher Scientific, Inc.). On the second day, the medium was changed to RPMI-1640 supplemented with 5\% FBS, 1\% penicillin/streptomycin and 1,10 or $30 \mu \mathrm{mol} / 1$ casticin $(98 \%$ purity; Sigma-Aldrich; Merck Millipore) prior to incubation for $72 \mathrm{~h}$. Untreated cells served as the control. A total of $4 \mathrm{~h}$ before the end of incubation, $20 \mu 1 \mathrm{MTT}(5 \mathrm{mg} / \mathrm{ml}$; Sigma-Aldrich; Merck Millipore) was added. Supernatants were subsequently discarded and $200 \mu \mathrm{l}$ dimethylsulfoxide was added to each well before shaking gently for $10 \mathrm{~min}$ to dissolve crystals. The absorbance of each well was measured at $570 \mathrm{~nm}$ using a Synergy HT microplate reader (BioTek Instruments, Inc., Winooski, VT, USA). The following formulae were used to calculate the survival and inhibitory rates of the tumor cells. Survival rate of tumor cells $(\%)=($ absorbance of treatment wells / absorbance of control well) $x 100$. Inhibitory rate of tumor cells $(\%)=$ (absorbance of control well - absorbance of treatment wells) / absorbance of control well x 100. Tests were performed in triplicate.

Enzyme-linked immunosorbent assay (ELISA). MGC803 cells were left untreated or treated with 1-30 $\mu \mathrm{mol} / 1$ casticin and nuclear protein was extracted using a NE-PER Nuclear and Cytoplasmic Extraction kit (Pierce; Thermo Fisher Scientific, Inc.). Nuclear protein concentrations were determined with the Bradford assay using the Coomassie Plus reagent (Thermo Fisher Scientific, Inc.). A total of $15 \mu \mathrm{g}$ nuclear protein from each treatment group was analyzed for Spl activity using the Transcription Factor ELISA kit (Affymetrix, Inc., Santa Clara, CA, USA). Sp1 antibody was used as the primary antibody and anti-rabbit IgG HRP was used as secondary antibody, which were provided in the kit. The absorbance was measured at a wavelength of $450 \mathrm{~nm}$ on a spectrophotometer (BioTek Instruments, Inc.).

Statistical analysis. The results were analyzed using SPSS software version 17.0 (SPSS, Inc., Chicago, IL, USA). Data are presented as the mean \pm standard deviation. Two groups of mean values were compared using Student's t-test. $\mathrm{P}<0.05$ was considered to indicate a statistically significant difference.

\section{Results}

Casticin increases the mRNA levels and protein expression of RECK in MGC803 cells. To determine the effect of casticin on the mRNA levels and protein expression of RECK, RT-qPCR and western blotting were performed, respectively. Western blot analysis indicated that the RECK protein band in the control group was relatively thin, whereas treatment with 1 , 10 or $30 \mu \mathrm{mol} / 1$ casticin significantly increased band thickness $(\mathrm{P}<0.05$; Fig. 1A). Results from RT-qPCR showed that treatment with 1,10 or $30 \mu \mathrm{mol} / 1$ casticin also significantly increased $R E C K$ mRNA levels in a dose-dependent manner $(\mathrm{P}<0.05$; Fig. 1B). These results suggest that casticin increases RECK mRNA levels and protein expression in MGC803 cells.

Casticin reduces RECK promoter methylation level, global DNA methylation level and nuclear methylation activity. To detect the effect of casticin on methylation, the EpiQuik DNMT kit was used. The results demonstrated that casticin decreased $R E C K$ promoter methylation level, global DNA methylation level and methylation activity in nuclear extracts in a dose-dependent manner. Treatment with $30 \mu \mathrm{mol} / 1$ casticin reduced $R E C K$ promoter methylation level by $31 \%$, global DNA methylation level by $39 \%$ and nuclear methylation activity by $71.6 \%$ (Table I). These results indicate that casticin reduces the $R E C K$ promoter methylation level, global DNA methylation level and nuclear methylation activity.

Casticin downregulates the mRNA levels and protein expression of DNMT1 in MGC803 cells. RT-qPCR and western blotting were performed to measure the DNMT1 mRNA and protein expression levels, respectively. Western blot analysis demonstrated that the DNMT1 protein band in the control was relatively thick, whereas treatment with 1,10 or $30 \mu \mathrm{mol} / 1$ casticin significantly decreased band thickness $(\mathrm{P}<0.05$; Fig. 2A). Quantification of mRNA levels and protein expression indicated that treatment with 1,10 or $30 \mu \mathrm{mol} / 1$ casticin significantly reduced levels of DNMT1 mRNA and protein in a dose-dependent manner $(\mathrm{P}<0.05$; Fig. $2 \mathrm{~B})$. These results suggest that casticin downregulates the levels of DNMT1 mRNA and protein in MGC803 cells.

Casticin inhibits the proliferation and DNA-binding activity of transcription factor Spl in MGC803 cells. To investigate the effect of casticin on MGC803 cell proliferation and the DNA-binding activity of Sp1 transcription factor, MTT assay and ELISA were performed, respectively. The MTT assay demonstrated that the proliferation rates of MGC803 cells following treatment with 10 and $30 \mu \mathrm{mol} / 1$ casticin were 44 


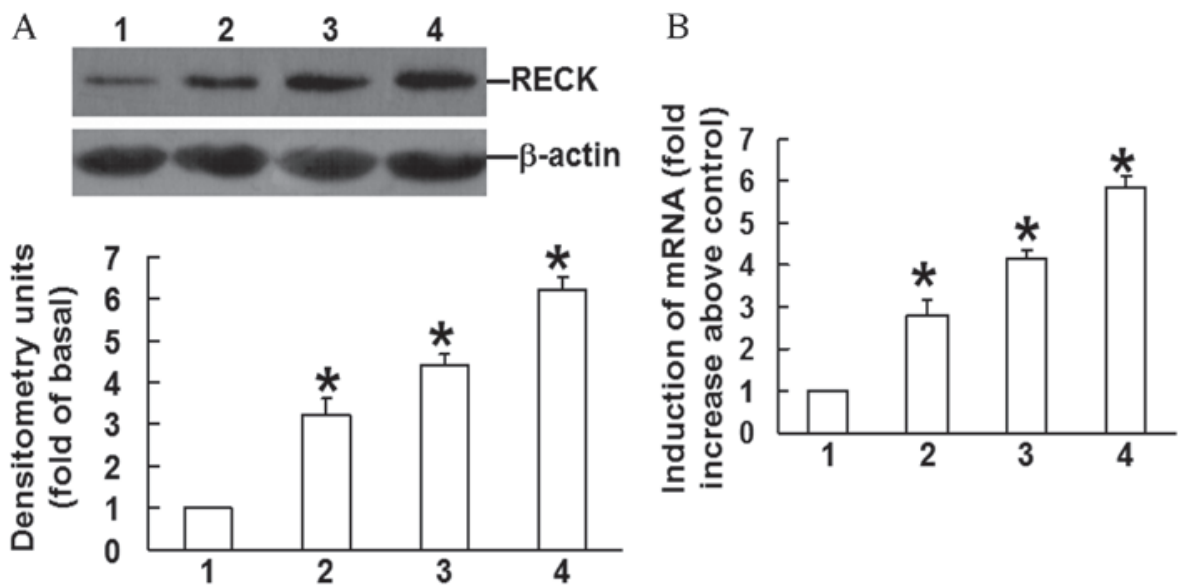

Figure 1. Effect of casticin on RECK mRNA and protein expression in MGC803 cells. (A) RECK protein expression detected by western blotting and quantification of protein expression. (B) Quantification of $R E C K \mathrm{mRNA}$ expression by reverse transcription-quantitative polymerase chain reaction. Data are expressed as mean \pm standard deviation. ${ }^{~} \mathrm{P}<0.05$ vs. control. 1 , control; 2 , treatment with $1 \mu \mathrm{mol} / 1 \mathrm{casticin} ; 3$, treatment with $10 \mu$ mol $/ 1$ casticin; 4 , treatment with $30 \mu \mathrm{mol} / 1$ casticin. RECK, reversion-inducing-cysteine-rich protein with kazal motifs.

and $23 \%$ of that in the control, respectively $(\mathrm{P}<0.05$; Fig. $3 \mathrm{~A})$. Furthermore, the results from ELISA indicated that treatment with casticin $(1,10$ and $30 \mu \mathrm{mol} / \mathrm{l})$ reduced the DNA-binding activity of Sp1 in MGC803 cells $(\mathrm{P}<0.05$; Fig. 3B). These results suggest that casticin inhibits the proliferation and DNA-binding activity of transcription factor Sp1 in MGC803 cells.

\section{Discussion}

$R E C K$ is a tumor suppressor gene that exists in multiple tissues and cells and regulates cell proliferation. In gastric, breast, esophageal and pancreatic cancer cells, RECK gene expression is low and usually accompanied by abnormal methylation $(26,27)$. The present study demonstrated that casticin upregulated RECK mRNA and protein expression in MGC803 gastric cancer cells. The activation of RECK was found to be associated with reduced methylation of its promoter region. In addition, the present study demonstrated that casticin inhibits DNMT1 expression in MGC803 cells and affects the DNA-binding activity of Sp1. This may subsequently inhibit the methylation of $R E C K$, thus inhibiting the proliferation of gastric cancer cells. Similarly, it has been determined in previous studies that some tumor suppressor genes silenced by supermethylation, including GSTPl and MGMT, are re-activated by certain exogenous drugs $(28,29)$.

Epigenetic chemotherapy is a type of novel therapeutic strategy for cancer that has been developed in recent years (30). In eukaryotic transcriptional regulation, DNA methylation is an important epigenetic mechanism and changes in methylation patterns may promote the occurrence of tumors. It has been over 40 years since abnormal DNA methylation was first identified in tumor cells (31). Hypomethylation and gene-specific hypermethylation have since been observed in all detected tumor types (32). Currently, DNA demethylation drugs including decitabine and azacytidine are clinically used to treat myelodysplastic syndrome (33). However, the clinical application of epigenetic chemotherapy in solid tumors such as gastric tumors requires further investigation. Although the toxicity of taxol in tumor cells is higher than that of casticin, it is less selective than casticin (34). Casticin causes no toxicity in healthy cells and tissues (23); however it significantly inhibits the proliferative activity of numerous malignant tumor cells (20). As a type of demethylation drug, casticin may become a novel preventive means for gastric cancer, due to its few adverse reactions.

In the current study, the activity of transcriptional factor Sp1 was analyzed, in order to further investigate the possible mechanism of action of casticin. Spl is the most important transcriptional factor in the Sp family, because it is the most relevant to methylation among all $\mathrm{Sp}$ members. Notably, $\mathrm{Sp} 1$ specifically binds to the GC box (GGGGCGGGG) or GT box (GGTGTGGGG) in target genes, resulting in the activation of transcription (35). Sp1 promotes the expression of a number of molecules that positively regulate cell cycles and affects the methylation of the DNA CpG island (36). In numerous tumor tissues, Sp1 expression is high and its activity is positively correlated with the degree of tumor invasion, but negatively correlated with patient prognosis $(37,38)$.

The present study demonstrated that Sp1 activity in MGC803 cells in the control group was high, but significantly decreased following treatment with different concentrations of casticin. There are Sp1 binding sites on DNMT1 (39) and Yu et al (40) observed that curcumin inhibits DNMT1 expression, possibly by inhibiting Sp1 activity. Similar results were observed by Du et al (41). Yie et al (42) also demonstrated that overexpression of $\mathrm{Sp} 1$ in live cancer cells promotes the expression of DNMT1. Therefore, the inhibition of Sp1 by casticin may lead to the reduced activity of DNMT1 and an inhibitory effect on methylation. However, further studies are necessary to elucidate whether casticin exerts its inhibitory effect on DNMT1 activity via Sp1.

In recent years, demethylation treatment has become an important method of tumor therapy. For example, 5-Aza-2'-deoxycytidine has been applied clinically in the treatment of myelodysplastic syndrome (43). In the present study, we demonstrates that casticin inhibits the proliferation of gastric cancer MGC803 cells by upregulating RECK 


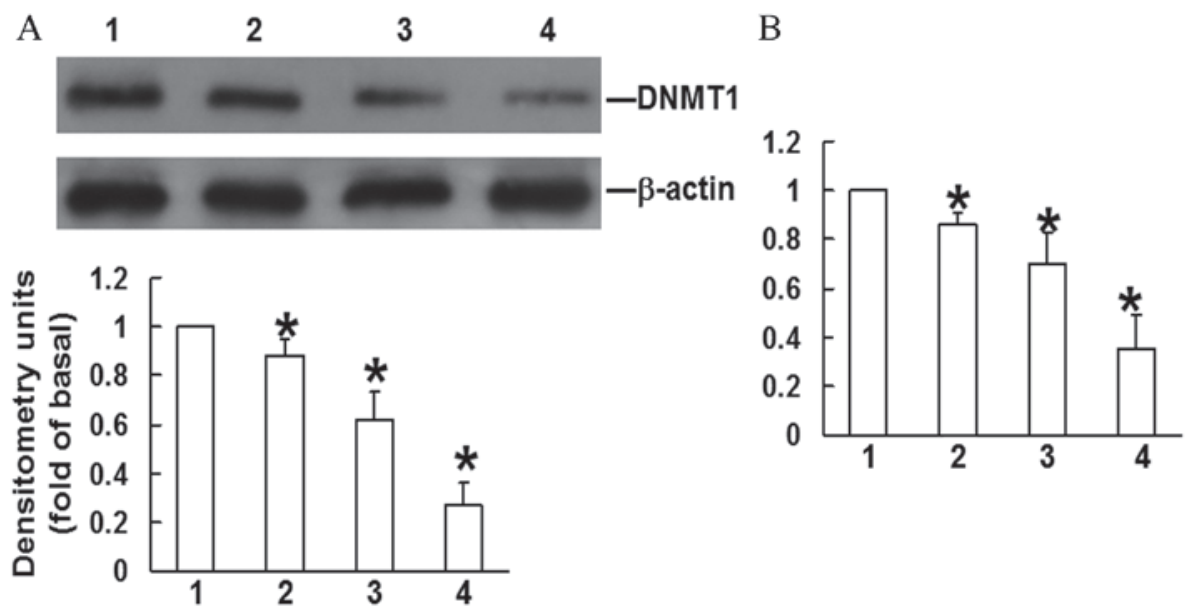

Figure 2. Effect of casticin on DNMT1 mRNA and protein expression in MGC803 cells. (A) DNMT1 protein expression detected by western blotting and quantification of protein expression. (B) DNMT1 mRNA levels were determined by reverse transcription-quantitative polymerase chain reaction and quantified. Data are expressed as mean \pm standard deviation. ${ }^{*} \mathrm{P}<0.05$ vs. control. 1 , control; 2 , treatment with $1 \mu \mathrm{mol} / 1$ casticin; 3 , treatment with $10 \mu \mathrm{mol} / 1$ casticin; 4 , treatment with $30 \mu \mathrm{mol} / 1$ casticin. DNMT1, DNA methyltransferase 1.
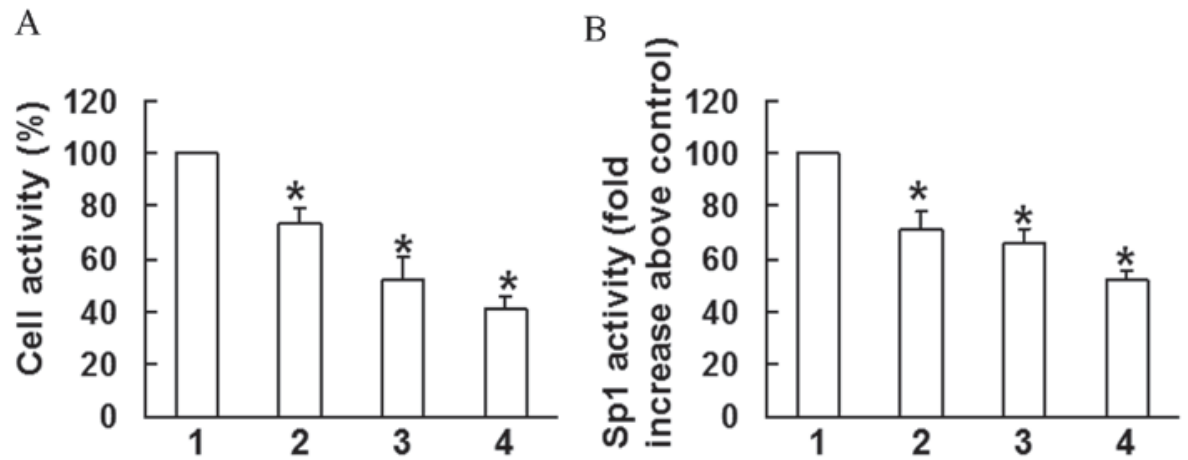

Figure 3. Anti-proliferative activity and Sp1 DNA-binding activity of casticin in MGC 803 cells. (A) Cell metabolic activity determined by MTT assay. (B) DNA-binding activity of Sp1 determined by ELISA. "P $<0.05$ vs. control. 1 , control; 2, treatment with $1 \mu \mathrm{mol} / 1$ casticin; 3 , treatment with $10 \mu$ mol/1 casticin; 4 , treatment with $30 \mu \mathrm{mol} / 1$ casticin.

gene expression and reducing intracellular methylation levels. Casticin is originated from natural plant, and its toxicity is relatively low. Therefore, casticin may have more extensive application where 5-aza-2'-deoxycytidine has little effect. Further research is required to investigate the effect of casticin on healthy cells and homeostasis, and the toxicity of casticin, in order to determine whether casticin may be developed as a novel methylation inhibitor.

\section{References}

1. Venerito M, Link A, Rokkas T and Malfertheiner P: Gastric cancer-clinical and epidemiological aspects. Helicobacter 21: (Suppl) S39-S44, 2016.

2. Schinzari G, Cassano A, Orlandi A, Basso M and Barone C: Targeted therapy in advanced gastric carcinoma: The future is beginning. Curr Med Chem 21: 1026-1038, 2014.

3. Osman MA, Bloom GS and Tagoe EA: Helicobacter pylori-induced alteration of epithelial cell signaling and polarity: A possible mechanism of gastric carcinoma etiology and disparity. Cytoskeleton (Hoboken) 70: 349-359, 2013.

4. Fukayama M, Hino R and Uozaki H: Epstein-Barr virus and gastric carcinoma: Virus-host interactions leading to carcinoma. Cancer Sci 99: 1726-1733, 2008.

5. Chen JN, He D, Tang F and Shao CK: Epstein-Barr virus-associated gastric carcinoma: A newly defined entity. J Clin Gastroenterol 46: 262-271, 2012.
6. Rusiecki JA, Al-Nabhani M, Tarantini L, Chen L, Baccarelli A and Al-Moundhri MS: Global DNA methylation and tumor suppressor gene promoter methylation and gastric cancer risk in an Omani Arab population. Epigenomics 3: 417-429, 2011.

7. Ooki A, Yamashita K, Yamaguchi K, Mondal A, Nishimiya H and Watanabe M: DNA damage-inducible gene, reprimo functions as a tumor suppressor and is suppressed by promoter methylation in gastric cancer. Mol Cancer Res 11: 1362-1374, 2013.

8. Liu S, Ren S, Howell P, Fodstad O and Riker AI: Identification of novel epigenetically modified genes in human melanoma via promoter methylation gene profiling. Pigment Cell Melanoma Res 21: 545-558, 2008.

9. Tanaka M, Chang P, Li Y, Li D, Overman M, Maru DM, Sethi S, Phillips J, Bland GL, Abbruzzese JL and Eng C: Association of CHFR promoter methylation with disease recurrence in locally advanced colon cancer. Clin Cancer Res 17: 4531-4540, 2011.

10. Coppedè F, Grossi E, Lopomo A, Spisni R, Buscema M and Migliore L: Application of artificial neural networks to link genetic and environmental factors to DNA methylation in colorectal cancer. Epigenomics 7: 175-186, 2015.

11. Takahashi C, Sheng Z, Horan TP, Kitayama H, Maki M, Hitomi K, Kitaura Y, Takai S, Sasahara RM, Horimoto A et al: Regulation of matrix metalloproteinase-9 and inhibition of tumor invasion by the membrane-anchored glycoprotein RECK. Proc Natl Acad Sci USA 95: 13221-13226, 1998.

12. Meng N, Li Y, Zhang H and Sun XF: RECK, a novel matrix metalloproteinase regulator. Histol Histopathol 23: 1003-1010, 2008. 
13. Clark JC, Thomas DM, Choong PF and Dass CR: RECK-a newly discovered inhibitor of metastasis with prognostic significance in multiple forms of cancer. Cancer Metastasis Rev 26: 675-683, 2007.

14. Noda M, Oh J, Takahashi R, Kondo S, Kitayama H and Takahashi C: RECK: A novel suppressor of malignancy linking oncogenic signaling to extracellular matrix remodeling. Cancer Metastasis Rev 22: 167-175, 2003.

15. Takenaka K, Ishikawa S, Kawano Y, Yanagihara K, Miyahara R, Otake Y, Morioka Y, Takahashi C, Noda M, Wada H and Tanaka F: Expression of a novel matrix metalloproteinase regulator, RECK, and its clinical significance in resected non-small cell lung cancer. Eur J Cancer 40: 1617-1623, 2004.

16. Overall CM and López-Otín C: Strategies for MMP inhibition in cancer: Innovations for the post-trial era. Nat Rev Cancer 2: 657-672, 2002

17. Ezzeldin HH, Lee AM, Mattison LK and Diasio RB Methylation of the DPYD promoter: An alternative mechanism for dihydropyrimidine dehydrogenase deficiency in cancer patients. Clin Cancer Res 11: 8699-8705, 2005

18. Tang SY, Zhong MZ, Yuan GJ, Hou SP, Yin LL, Jiang H and Yu ZY: Casticin, a flavonoid, potentiates TRAIL-induced apoptosis through modulation of anti-apoptotic proteins and death receptor 5 in colon cancer cells. Oncol Rep 29: 474-480, 2013.

19. Beutler JA, Hamel E, Vlietinck AJ, Haemers A, Rajan P, Roitman JN, Cardellina JH II and Boyd MR: Structure-activity requirements for flavone cytotoxicity and binding to tubulin. J Med Chem 41: 2333-2338, 1998.

20. Kikuchi H, Yuan B, Nishimura Y, Imai M, Furutani R, Kamoi S, Seno M, Fukushima S, Hazama S, Hirobe C, et al: Cytotoxicity of Vitex agnus-castus fruit extract and its major component casticin, correlates with differentiation status in leukemia cell lines. Int J Oncol 43: 1976-1984, 2013

21. Liu E, Kuang Y, He W, Xing X and Gu J: Casticin induces human glioma cell death through apoptosis and mitotic arrest. Cell Physiol Biochem 31: 805-4814, 2013.

22. Zhou Y, Tian L, Long L, Quan M, Liu F and Cao J: Casticin potentiates TRAIL-induced apoptosis of gastric cancer cells through endoplasmic reticulum stress. PLoS One 8: e58855, 2013.

23. Rasul A, Zhao BJ, Liu J, Liu B, Sun JX, Li J and Li XM: Molecular mechanisms of casticin action: An update on its antitumor functions. Asian Pac J Cancer Prev 15: 9049-9058, 2014.

24. Livak KJ and Schmittgen TD: Analysis of relative gene expression data using real-time quantitative PCR and the 2(-Delta Delta C (T)) Method. Methods 25: 402-408, 2001.

25. Liu Z, Liu S, Xie Z, Blum W, Perrotti D, Paschka P, Klisovic R, Byrd J, Chan KK and Marcucci G: Characterization of in vitro and in vivo hypomethylating effects of decitabine in acute myeloid leukemia by a rapid, specific and sensitive LC-MS/MS method. Nucleic Acids Res 35: e31, 2007.

26. Noda M, Takahashi C, Matsuzaki T and Kitayama H: What we learn from transformation suppressor genes: Lessons from RECK. Future Oncol 6: 1105-1116, 2010.

27. Pan Y, Liang H, Chen W, Zhang H, Wang N, Wang F, Zhang S, Liu Y, Zhao C, Yan X, et al: microRNA-200b and microRNA-200c promote colorectal cancer cell proliferation via targeting the reversion-inducing cysteine-rich protein with Kazal motifs. RNA Biol 12: 276-289, 2015.
28. Niture SK, Velu CS, Smith QR, Bhat GJ and Srivenugopal KS: Increased expression of the MGMT repair protein mediated by cysteine prodrugs and chemopreventative natural products in human lymphocytes and tumor cell lines. Carcinogenesis 28 : 378-389, 2007.

29. Mahon KL, Qu W, Devaney J, Paul C, Castillo L, Wykes RJ, Chatfield MD, Boyer MJ, Stockler MR, Marx G, et al: Methylated Glutathione S-transferase 1 (mGSTP1) is a potential plasma free DNA epigenetic marker of prognosis and response to chemotherapy in castrate-resistant prostate cancer. Br J Cancer 111: 1802-1809, 2014

30. Thomas X: DNA methyltransferase inhibitors in acute myeloid leukemia: Discovery, design and first therapeutic experiences. Expert Opin Drug Discov 7: 1039-1051, 2012.

31. Halpern BC, Halpern RM, Chaney SQ and Smith RA: Reversal of malignant transformation by tumor DNA. Proc Natl Acad Sci USA 67: 1827-1833, 1970.

32. Klutstein M, Nejman D, Greenfield R and Cedar H: DNA methylation in cancer and aging. Cancer Res 76: 3446-3450, 2016.

33. Si J, Boumber YA, Shu J, Qin T, Ahmed S, He R, Jelinek J and Issa JP: Chromatin remodeling is required for gene reactivation after decitabine-mediated DNA hypomethylation. Cancer Res 70: 6968-6977, 2010.

34. Remberg P, Björk L, Hedner T and Sterner O: Characteristics, clinical effect profile and tolerability of a nasal spray preparation of Artemisia abrotanum L. for allergic rhinitis. Phytomedicine 11: 36-42, 2004

35. Collins $\mathrm{M}$ and Bornstein P: SP1-binding elements, within the common metaxin-thrombospondin 3 intergenic region, participate in the regulation of the metaxin gene. Nucleic Acids Res 24: 3661-3669, 1996.

36. Zhang L, Yang W, Zhu X and Wei C: p53 inhibits the expression of $\mathrm{p} 125$ and the methylation of POLD1 gene promoter by downregulating the Sp1-induced DNMT1 activities in breast cancer. Onco Targets Ther 9: 1351-1360, 2016.

37. Sankpal UT, Goodison S, Abdelrahim M and Basha R: Targeting $\mathrm{Sp} 1$ transcription factors in prostate cancer therapy. Med Chem 7: 518-525, 2011.

38. Li L and Davie JR: The role of Sp1 and Sp3 in normal and cancer cell biology. Ann Anat 192: 275-283, 2010.

39. Thomas K, Wu J, Sung DY, Thompson W, Powell M, McCarrey J, Gibbs R and Walker W: SP1 transcription factors in male germ cell development and differentiation. Mol Cell Endocrinol 270: $1-7,2007$.

40. Yu J, Peng Y, Wu LC, Xie Z, Deng Y, Hughes T, He S, Mo X, Chiu M, Wang QE, et al: Curcumin down-regulates DNA methyltransferase 1 and plays an anti-leukemic role in acute myeloid leukemia. PLoS One 8: e55934, 2013.

41. Du L, Xie Z, Wu LC, Chiu M, Lin J, Chan KK, Liu S and Liu Z: Reactivation of RASSF1A in breast cancer cells by curcumin. Nutr Cancer 64: 1228-1235, 2012.

42. Yie Y, Zhao S, Tang Q, Zheng F, Wu J, Yang L, Deng S and Hann SS: Ursolic acid inhibited growth of hepatocellular carcinoma HepG2 cells through AMPK $\alpha$-mediated reduction of DNA methyltransferase 1. Mol Cell Biochem 402: 63-74, 2015.

43. Issa JP, Garcia-Manero G, Giles FJ, Mannari R, Thomas D, Faderl S, Bayar E, Lyons J, Rosenfeld CS, Cortes J and Kantarjian HM: Phase 1 study of low-dose prolonged exposure schedules of the hypomethylating agent 5-aza-2'-deoxycytidine (decitabine) in hematopoietic malignancies. Blood 103 1635-1640, 2004. 